MARTIN JURKOVIČ, Ph.D. ${ }^{1}$

(Corresponding author)

E-mail: martin.jurkovic@fpedas.uniza.sk

TOMÁŠ KALINA, Ph.D. ${ }^{1}$

E-mail: tomas.kalina@fpedas.uniza.sk

TOMÁŠ SKRÚCANÝ, Ph.D. ${ }^{1}$

E-mail: tomas.skrucany@fpedas.uniza.sk

PIOTR GORZELAŃCZYK, Ph.D. ${ }^{2}$

E-mail: pgorzelanczyk@pwsz.pila.pl

VLADIMÍR LUPTÁK, Ph.D. ${ }^{3}$

E-mail: luptak@mail.vstecb.cz

${ }^{1}$ Faculty of Operation and Economics of Transport and Communication, University of Zilina

Univerzitná 1, 01026 Žilina, Slovakia

${ }^{2}$ Stanisław Staszic University of Applied Sciences in Pila

Ul. Podchorążych 10, 64-920 Piła, Poland

${ }^{3}$ Department of Transport and Logistics

Faculty of Technology, Institute of Technology

and Business in Ceske Budejovice

Okružní 10, 37001 České Budějovice, Czech Republic
Traffic and Environment (Ecology) Original Scientific Paper Submitted: 15 Apr. 2020 Accepted: 25 June 2020

\title{
ENVIRONMENTAL IMPACTS OF INTRODUCING LNG AS ALTERNATIVE FUEL FOR URBAN BUSES - CASE STUDY IN SLOVAKIA
}

\begin{abstract}
The aim of the paper is to assess the possibility of decreasing the chosen environmental indicators like energy consumption, greenhouse gas (GHG) production and other exhaust pollutants in the selected region in Slovakia by introducing Liquefied Natural Gas (LNG) buses into bus transport. The assessment is carried out by comparing the consumption and emissions of current buses (EURO 2) in real operation, with potential buses (EURO 6) and with pilot LNG buses testing on the same lines. Comparison took place under the same conditions over the same period. The study measures the energy consumption and GHG production per bus. The research paper also compares two methodologies of calculation. The first calculation is according to the European Standard EN 16258: 2012 which specifies the general methodology for evaluation and declaration of energy consumption and GHG emissions (all services - cargo, passengers or both). The second calculation is according to the Handbook of Emission Factors for Road Transport (HBEFA). The results of the calculation are compared by both methods, and the most suitable version of the bus in terms of GHG emissions is proposed.
\end{abstract}

\author{
KEY WORDS \\ liquefied natural gas; diesel; bus; GHG emissions; \\ consumption;
}

\section{INTRODUCTION}

Petrol and diesel should be replaced by alternative fuels. Alternative fuel vehicles should be fiscally preferred, and also they should be exempted from different registration fees [1]. The Ministry of Economy of the Slovak Republic has prepared twelve measures to promote alternative fuels, such as electricity, liquefied and compressed natural gas, liquefied petroleum gas, hydrogen or liquid biofuels. The Ministry of Economy of the Slovak Republic wants to stimulate the sale of vehicles with alternative drive, such as direct financial incentives. The construction of alternative fuel infrastructure should also be encouraged [2]. Another measure is also to shorten the depreciation period for such vehicles or to introduce low-emission zones in towns and villages to which only alternative fuel vehicles should have access. This should be seen as an EU support for alternative fuels [3]. At the end of the $20^{\text {th }}$ century, the production of GHG from the transport sector increased by $250 \%$ (since 1970). The increase in transport sector is higher than in other sectors. Therefore, solutions are currently being sought to reduce the greenhouse gas emissions from transport [4]. 
The case study deals with the issues of emission production in bus transport in Slovakia. It compares the production of the GHG emissions of the current diesel bus fleet operated in the Central Slovakia. Emissions are calculated according to real data on four transport lines by two methods. Each line has a different profile, so the research shows the average operating parameters in bus transport in Slovakia. The daily range, the number of stops as well as the route profile were set according to the average real parameters on the given lines. The current fleet was tested and compared with EURO 6 emission class buses and LNG buses. The amount of emissions from bus operation is one of the important factors influencing the choice of a new vehicle fleet.

\section{LITERATURE REVIEW}

The environmental impacts caused by public bus transportation systems have been solved in previous studies [5, 6], that examined the benefits of alternative fuels in bus transportation. Several other studies $[7,8]$ focused on emission production have been carried out in the past. The results show that $\mathrm{CO}_{2}$ levels have increased by about $7 \%$ over the last ten years. The transport sector produces around $23 \%$ of total $\mathrm{CO}_{2}$ emissions, representing almost a quarter of the total $\mathrm{CO}_{2}$ produced [9]. Carbon dioxide equivalent $\mathrm{CO}_{2 \mathrm{e}}$ is a standard unit for measuring carbon footprints. Carbon footprint consisting of lots of different greenhouse gases can be expressed as a single number - $\mathrm{CO}_{2 \mathrm{e}}[10]$.

Bus transport in Slovakia is still the most widespread way of transporting people for short and medium distances. Most often it is about transporting people to work or school. Over the last decade, bus availability in Slovakia has been at the same level [11]. Currently, the main bus fleet in Slovakia is represented by diesel buses, electric buses and Compressed Natural Gas (CNG) buses. LNG buses are currently not used in bus transport in Slovakia. One of the main reasons is the lack of sufficient infrastructure [12].

The use of natural gas in the form of CNG in bus transport is verified and used in many cities in Slovakia and in other countries LNG is emerging as a new alternative [13]. The greatest advantage of LNG buses is a higher total range (approx. 750 $\mathrm{km}$, while in CNG version it is only about $350 \mathrm{~km}$ ) [14]. Another advantage is a significantly shorter refuelling time (LNG takes about 5 minutes, CNG approx. 20-30 minutes) and the fact that the tanks are not placed on the roof, resulting in a reduction of the centre of gravity and the safer passing under the overpasses [15].

Natural gas has many benefits as a fuel in transportation. Compared with automotive gasoline the diesel fuel is produced by burning fewer impurities [16]. Natural gas is composed of methane (8399.7\%), ethane, propane, butane, and nitrogen and has the lowest carbon content compared to petroleum fuels [17]. During the combustion process, natural gas emits less $\mathrm{CO}_{2}$ and less other pollutants than diesel fuel [18]. Previous studies compared natural gas and diesel and they show that natural gas can potentially reduce $\mathrm{CO}_{2}$ up to $20 \%, \mathrm{NO}_{\mathrm{x}}$ up to $90 \%$ and $\mathrm{SO}_{\mathrm{x}}$ and particular emissions by almost $100 \%[19,20]$. The biggest problem in Slovakia is to identify ways in which to supply LNG fuel stations and the increased acquisition costs of LNG buses in comparison with diesel versions [21].

One of the limiting factors for the use of natural gas at normal temperature and pressure is its gaseous state [22]. These shortcomings are to a certain extent circumvented using natural gas at a higher pressure (CNG - 20 to $25 \mathrm{MPa}$ ) or low temperature $\left(\mathrm{LNG}-162^{\circ} \mathrm{C}\right)$. By liquefaction, the original volume of natural gas decreases to one-sixth [23].

In addition to the already mentioned alternative fuels, there are other fuels whose emissions are incomparably lower than those of traditional fossil fuels. There had been many previous studies comparing alternative drivetrains for light duty vehicles and buses [24, 25]. Hydrogen drivetrain currently combines the best of fossil and electric drivetrain. It is refuelled quickly and similarly to petrol cars. The range is the same as petrol vehicles, but the impact on the environment is smaller than with electric ones. The vehicles with hydrogen fuel cells can refuel the tank as fast as traditional gas-powered vehicles. Hydrogen is considered a highly explosive type of gas. Hydrogen fuel cells are the technology of the future, but currently economically unprofitable. Insufficient infrastructure in the form of cryogenic hydrogen refuelling stations is also a weak spot. However, electric cars also face the same challenges, especially where their penetration is rising too fast due to subsidies and tax breaks [26].

Developments in the production of greenhouse gas emissions from transport in Slovakia are influenced by environmentally unfavourable road transport. In 2017, greenhouse gas emissions were recalculated using the COPERT V methodology and the 


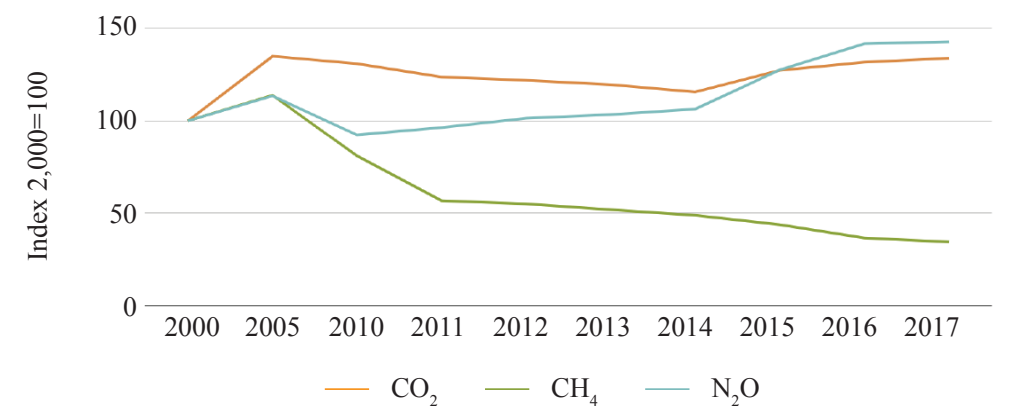

Figure 1 - Development of greenhouse gas emissions from transport in Slovakia [26]

values of $\mathrm{CH}_{4}$ and $\mathrm{N}_{2} \mathrm{O}$ emissions recorded a significant decrease. In the period from 2000 to 2014, $\mathrm{N}_{2} \mathrm{O}$ emissions were of a balanced nature with minimal year-on-year fluctuations. Only $\mathrm{CH}_{4}$ emissions decreased in the period from 2000 to 2017, which represented a decrease of $65.5 \%$ compared to 2000 . The most unfavourable were the $\mathrm{CO}_{2}$ emissions, which recorded year-on-year increases, while in 2017 the increase was $71.05 \%$ compared to 2000 . In the period from 2000 to 2017 , despite the fluctuating nature, $\mathrm{CO}_{2}$ and $\mathrm{N}_{2} \mathrm{O}$ emissions developed unfavourably. $\mathrm{CH}_{4}$ emissions decreased throughout the period under review. $\mathrm{CO}_{2}$ emissions from transport increased by $33.7 \%$ between 2000 and 2017, despite a year-on-year decrease and increase until 2014, after which they increased. The development of emissions is shown in Figure 1. $\mathrm{N}_{2} \mathrm{O}$ emissions in the observed period recorded a more significant decrease until 2010 and after this year they already had a growing trend. After 2010, $\mathrm{N}_{2} \mathrm{O}$ emissions grew at a slower pace until 2014, and after that year, a more significant increase continued until 2017. In the period 2000-2017, the increase was $42.7 \%$. $\mathrm{CH}_{4}$ emissions from transport are the most positive, with a decrease in 2017 of $65.5 \%$ compared to 2000 [27].

For this reason, natural gas can be regarded as one of the fuel options for transport, either in the form of compressed natural gas or in liquefied natural gas. Currently, 12 public CNG filling stations and one private LNG station are available in Slovakia [12]. With respect to the most efficient use of capacities, all LNG filling stations for truck and bus transport should be in the L-CNG version, which would allow the use of natural gas as a fuel in both CNG and LNG forms [28]. In terms of infrastructure building, three to five public filling stations at LNG by 2025 seem to be the optimum conditions for the Slovak Republic. The necessary average distance between filling stations should be maximally 400 kilometres for road transport [29].

\section{RESEARCH METHODOLOGY}

European Standard EN 16258: 2012 specifies the methodology for evaluation and declaration of energy consumption and GHG production from transport services (cargo, passengers or both). It specifies general principles, definitions, system boundaries, methods of calculation, allocation rules (allocation, assignment) and recommendations on information to support standardized, accurate, reliable, and verifiable declarations [30, 31].

The methodology for calculating GHG emission and its specific steps based on this standard are presented in a study by Skrucany \& Gnap [30].

The methodology does not consider only the secondary production of GHG and energy consumed during the fuel combustion (energy conversion from the chemical energy of the fuel to the mechanical energy for vehicle movement), as well as primary, incurred in the extraction, production and distribution of the fuel to the consumer [30].

\section{Overall energy consumption}

$E_{C P V}^{W}=S_{k m} \cdot e_{w} ; \quad E_{C P V}^{t}=S_{k m} \cdot e_{t}$

where:

$E_{C P V}^{w}$ - energy consumption by vehicles according to the "wtw (well-to-wheel)" approach $[\mathrm{MJ} / 100 \mathrm{~km}]$;

$E_{C P V}^{t}$ - energy consumption by vehicles according to the "ttw (tank-to-wheel)" approach $[\mathrm{MJ} / 100 \mathrm{~km}]$;

$S_{k m}$ - vehicle fuel consumption [1/100km];

$e_{w}$ - energy factor " $w t w$ " for consumed fuel $[\mathrm{MJ} / \mathrm{l}]$

$e_{t} \quad-$ energy factor " $t$ tw" for consumed fuel $[\mathrm{MJ} / \mathrm{l}]$.

\section{Overall emissions production}

$G_{C P V}^{w}=S_{k m} \cdot g_{w} ; G_{C P V}^{t}=S_{k m} \cdot g_{t}$

where: 
$G_{C P V}^{w}-$ amount of GHG produced by vehicles according to the "wtw" approach $\left[\mathrm{gCO}_{2 \mathrm{e}}\right]$;

$G_{C P V}^{t}$ - amount of GHG produced by vehicles according to the " $\mathrm{ttw}$ " approach $\left[\mathrm{gCO}_{2 \mathrm{e}}\right]$;

$g_{w}-$ emission factor "wtw" for consumed fuel $\left[\mathrm{gCO}_{2 \mathrm{e}} / \mathrm{MWh}\right]$;

$g_{t} \quad$ - emission factor " $t$ tw" for consumed fuel $\left[\mathrm{gCO}_{2 \mathrm{e}} / \mathrm{MWh}\right.$.

The Handbook of Emission Factors for Road Transport (HBEFA) provides emission factors, i.e. the specific emission in $\mathrm{g} / \mathrm{km}$ for all current vehicle categories (PC, LDV, HDV, buses and motorcycles), each divided into different categories, for a wide variety of traffic situations [32]. The assessment of HBEFA emission production has been solved in several research works [33, 34]. In this paper we used the latest HBEFA 3.3 version. Traffic simulation using HBEFA estimates emissions from the traffic situation and vehicle type.

\section{RESEARCH RESULTS}

This study compares the environmental aspects of different buses in the same operation. The research was carried out by solo buses from the manufacturer Solbus (diesel EURO 2, diesel EURO 6 and LNG bus shown in Figure 2) were tested on 4 lines in the year 2018.

In order to determine the average consumption, buses were deployed in different modes of operation [35]. The measurements were performed on all lines by one driver, in the same weather, at the same time of day, with the same number of passengers. Buses were operated in a shuttle service in the city of Dunajska Streda (line A - average distance between two stops: $1.2 \mathrm{~km}$, average speed: $42 \mathrm{~km} / \mathrm{h}$ ), in intermodal transport on the line Voderady - Trnava (line B - average distance between two stops: 28 $\mathrm{km}$, average speed: $67 \mathrm{~km} / \mathrm{h}$ ), in urban conditions in the town Prievidza (line $\mathrm{C}$ - average distance between two stops: $6.5 \mathrm{~km}$, average speed: $52 \mathrm{~km} / \mathrm{h}$ ) and in the suburban connection Zvolen - Cerin (line $\mathrm{D}$ - average distance between two stops: $22 \mathrm{~km}$, average speed: $64 \mathrm{~km} / \mathrm{h}$ ). The routes of the tested lines are shown in Figure 3. The number of the test days was not the same. It depended on the availability of transport company buses for the research. Minimum test time was set to 4 days.

The assessment is carried out by comparing the consumption and GHG emissions of current buses (EURO 2) in real operation, with potential buses (EURO 6) and with pilot LNG buses testing on the same routes/lines. Comparison took place under the same conditions over the same time period. The annual range of the currently used diesel bus is 49,700 $\mathrm{km}$.

The calculation of the average fuel consumption during LNG bus testing is shown in Table 1. It is the sum of the distances during the reference period on the selected lines as well as the amount of LNG fuelled.
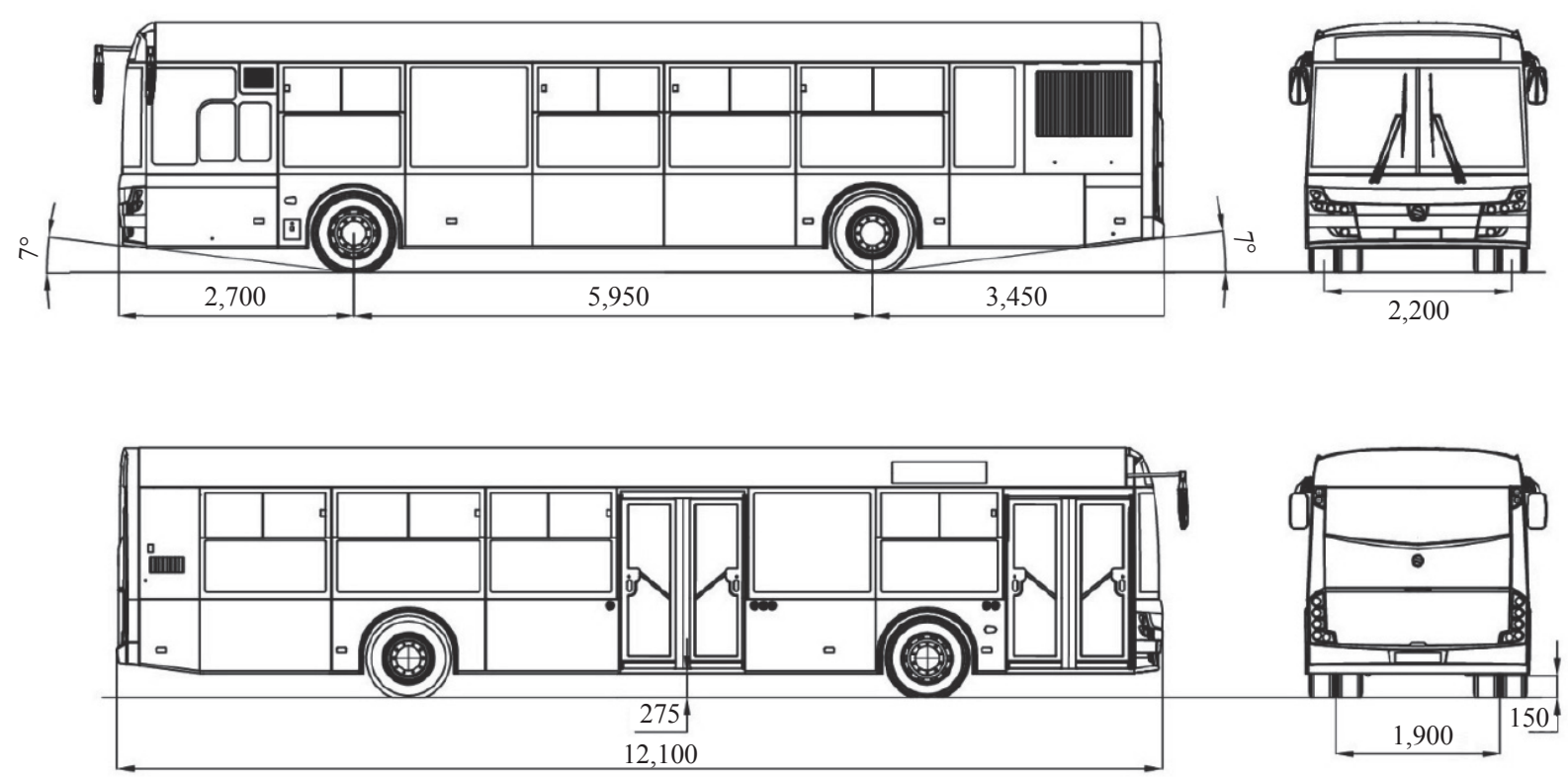

Figure 2 - Basic dimensions of the $L N G$ bus 
Table 1 - Average consumption on the lines - LNG buses

\begin{tabular}{||c|c|c|c|c||}
\hline Line & Days of testing & Total distance $[\mathrm{km}]$ & Total fuel consumption $[\mathrm{kg}]$ & $\begin{array}{c}\text { Average LNG fuel consumption } \\
{[\mathrm{kg} / 100 \mathrm{~km}]}\end{array}$ \\
\hline \hline A & 13 & 816 & 228 & 27.95 \\
\hline B & 4 & 921 & 290 & 31.49 \\
\hline C & 4 & 475 & 153 & 32.21 \\
\hline D & 9 & 2,205 & 676 & 30.70 \\
\hline
\end{tabular}

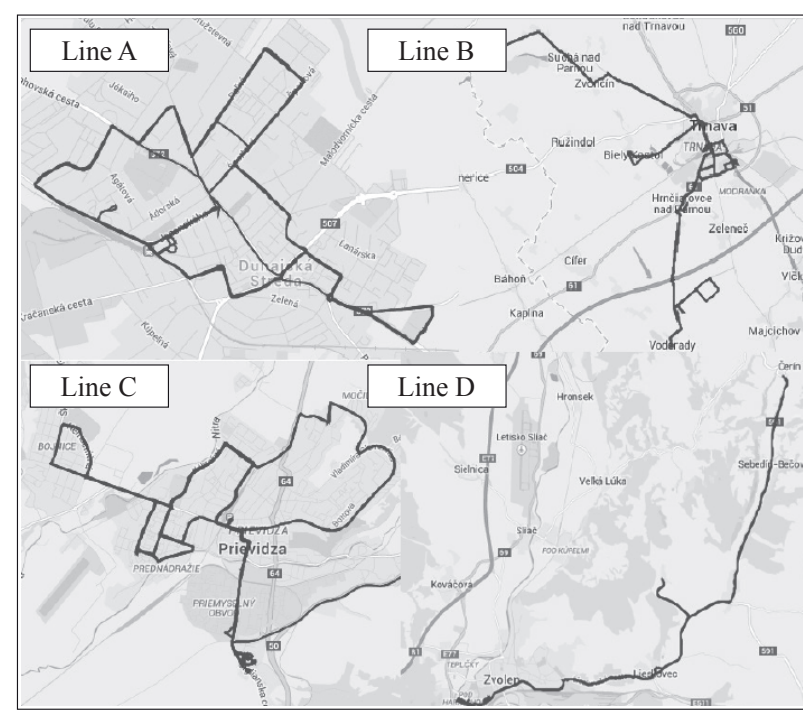

Figure 3 - Selected test lines for buses

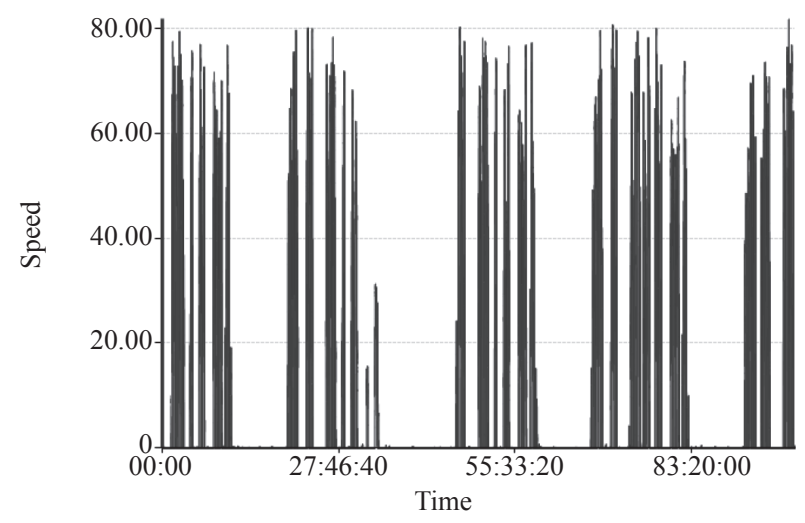

Figure 4 - Comparison of the speed of LNG buses on tested line $B$

The results show that the average LNG fuel consumption was lower than declared by the producer (the declared fuel consumption by the producer is $32 \mathrm{~kg} / 100 \mathrm{~km}$ ).

The vehicle speed profile is shown in Figure 4. This is an example of the real actual vehicle speed reached during the measurement (axis $\mathrm{Y}$ ) and elapsed time of measuring (axis X). There are visible five groups of speed columns separated by gaps. This fact represents five measuring days - vehicle operating time - and the gaps are night hours, when the vehicle was out of operation. This is the speed profile of the vehicle operated on line B. Other vehicles on other lines reached similar profiles.

The HBEFA database application estimates the emission factors of several pollutants per vehicle category, EURO stage, specific year and for a wide variety of traffic situations. The traffic situations are mainly represented by four parameters: area type (rural, urban), road type, road speed limit and service level (free flow, heavy, saturated, and stop-and-go).

It provides sufficiently accurate data and allows the user to select the accurate values of factors according to immediate conditions of vehicle operation.

The input parameters for the simulation and selection of precise conditions of the vehicle operation were emission limits of vehicles (EURO 2 and EURO 6), speed profile of vehicles operated on lines, vertical alignments of the lines and the most important - average fuel consumption.

The calculation of the average fuel consumption during diesel EURO 2 bus tests is shown in Table 2. It is the sum of the distances during the reference period on the selected lines as well as the amount of diesel fuelled. The results about fuel consumption are introduced in two different units per $100 \mathrm{~km}$ - litres and kilograms. Both units are used because of the common and most used expression of the consumed volume of diesel (litres) and better comparison to the consumed amount of LNG expressed in $\mathrm{kg}$. It is possible to compare the results also in the amount of consumed fuel ( $\mathrm{kg}$ to $\mathrm{kg}$ ) and in the following step of consumed energy (MJ).

The calculation of the average fuel consumption during diesel EURO 6 buses testing is shown in Table 3. It is the sum of the distances during the reference period on the selected lines as well as the amount of diesel fuelled.

The results show that the average diesel fuel consumption was higher than declared by the producer (declared fuel consumption by the producer is $29 \mathrm{l} / 100 \mathrm{~km}$ ). 
Table 2 - Average consumption on the lines - Diesel buses EURO 2

\begin{tabular}{||c|c|c|c|c|c||}
\hline Line & Days of testing & $\begin{array}{c}\text { Total } \\
\text { distance }[\mathrm{km}]\end{array}$ & $\begin{array}{c}\text { Total fuel } \\
\text { consumption [1] }\end{array}$ & $\begin{array}{c}\text { Average diesel } \\
\text { consumption }[1 / 100 \mathrm{~km}]\end{array}$ & $\begin{array}{c}\text { Average diesel } \\
\text { consumption }[\mathrm{kg} / 100 \mathrm{~km}]\end{array}$ \\
\hline \hline A & 12 & 753 & 239 & 31.7 & 26.4 \\
\hline B & 5 & $1,151.25$ & 398 & 34.6 & 28.8 \\
\hline C & 4 & 475 & 170 & 35.8 & 29.8 \\
\hline D & 8 & 1,960 & 601 & 30.7 & 25.5 \\
\hline \multicolumn{2}{|l}{ Average consumption on A-D lines } \\
\hline
\end{tabular}

Table 3 -Average consumption on the lines - Diesel buses EURO 6

\begin{tabular}{|c|c|c|c|c|c||}
\hline Line & Days of testing & $\begin{array}{c}\text { Total } \\
\text { distance }[\mathrm{km}]\end{array}$ & $\begin{array}{c}\text { Total fuel } \\
\text { consumption [1] }\end{array}$ & $\begin{array}{c}\text { Average diesel } \\
\text { consumption }[1 / 100 \mathrm{~km}]\end{array}$ & $\begin{array}{c}\text { Average diesel } \\
\text { consumption [kg/100 km] }\end{array}$ \\
\hline \hline A & 13 & 815 & 239.7 & 29.4 & 24.5 \\
\hline B & 4 & 921 & 302.6 & 32.9 & 27.3 \\
\hline C & 5 & 594 & 200.8 & 33.8 & 28.1 \\
\hline D & 9 & 2,205 & 671.4 & 30.5 & 25.3 \\
\hline \multicolumn{2}{|r|}{ Average consumption on A-D lines } \\
\hline
\end{tabular}

\section{DISCUSSION}

The amount of consumed fuel should be multiplied by the energy factor for that fuel from Appendix A (Energy and GHG Emission Factors) from the used standard EN 16,258 for the calculation of the overall energy intensity [31]. The energy factors for diesel were taken from the standard, the factors for LNG were taken from US Energy Information Administration [36] and compared to the energy factors from the standard valid for CNG.

The result of this comparison and investigation is that CNG and LNG are the same fuels (regarding the chemical composition) with different physical characteristics. The physical form is different - one is compressed gas, the other is liquefied gas, thus liquid. Thanks to these facts we can consider the emission factor for CNG and LNG of the same value (mass amount) in the calculations.
Figure 5 describes the value of energy consumption of each compared bus. Left columns " $t$ tw" describe the value of energy consumed during combustion of the fuel. Right columns "wtw" consider both the primary and secondary consumption. The results represent differences between older and newer diesel buses and buses equipped by an LNG spark ignition Internal Combustion Engine (ICE). Opposite to the fact that the LNG bus equipped by new and environmentally friendly drive, it reaches higher values of energy intensity than diesel buses. This reality is caused by the amount of consumed LNG during bus operation and the energy density of LNG as a fuel.

Figure 6 describes the value of emission production of each compared bus. Left columns " $\mathrm{ttw}$ " describe the value of the secondary emissions produced during the combustion of the fuel. Right columns "wtw" consider both primary and secondary

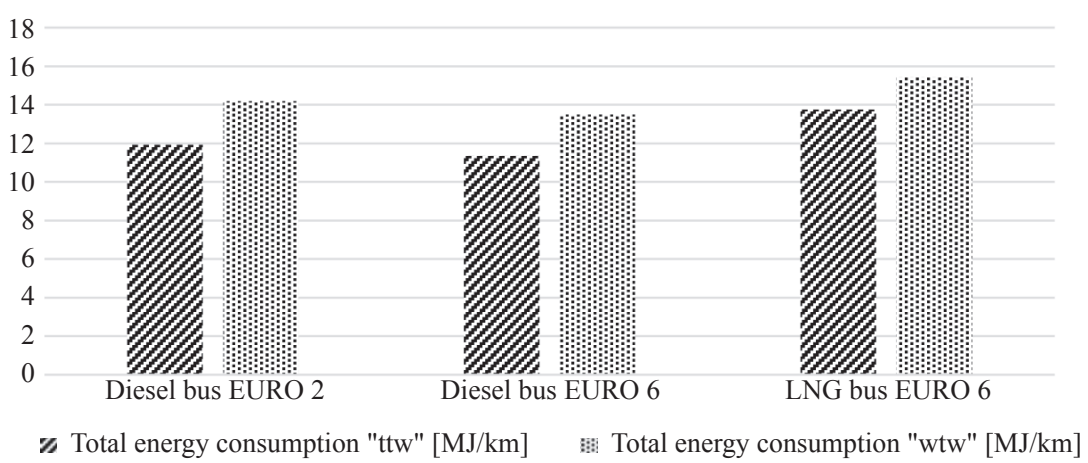

Figure 5 - Overall consumption of energy 
emissions. The results show that the emission production of the EURO 6 diesel bus is 3.17\% higher than the LNG version (tank-to-wheels assessment).

To ensure relevant results, the specification of the inputs was based on real conditions in which the selected types of buses were tested. The speed specification was also based on the measurement results.

The results based on HBEFA for $\mathrm{CO}_{2 \mathrm{e}}$ are compared in Figure 7 ("ttw" assessment).

Figure 7 describes the value of $\mathrm{CO}_{2 \mathrm{e}}$ of each compared bus. It is necessary to provide the fact, that HBEFA software cannot evaluate the $\mathrm{CO}_{2 \mathrm{e}}$ emissions; it is possible to get just separated emission gases like $\mathrm{CO}_{2}, \mathrm{CH}_{4}, \mathrm{NH}_{3}, \mathrm{CO}, \mathrm{PM}, \mathrm{N}_{2} \mathrm{O}, \mathrm{NO}_{\mathrm{x}}$ and others. Value $\mathrm{CO}_{2 \mathrm{e}}$ from HBEFA was calculated according to the GWP (Global Warming Potential) of each emission gas.

The results show that the lowest $\mathrm{CO}_{2 \mathrm{e}}$ production is in the LNG version of the bus. The highest $\mathrm{CO}_{2 \mathrm{e}}$ production is in the diesel EURO 2 version. In terms of the renewal of the bus fleet regarding environmental impacts, it is necessary to compare the LNG version with the diesel version of EURO 6. The results show that the GHG emission production of the EURO 6 diesel bus is $2.70 \%$ higher than the LNG version.
According to the current scientific and technical procedures, buses are divided into five categories according to fuel types [37]. The HBEFA calculation was also based on this division. By comparing our results with studies already carried out that measured emissions of LNG buses and diesel buses under the same or similar conditions, it can be concluded that our results in principle coincide with the research carried out in other regions [38, 39].

The comparison of $\mathrm{CO}_{2 \mathrm{e}}$ emissions of European Standard EN 16258: 2012 and the calculation using HBEFA is shown in Figure 8. Relevant comparison of $\mathrm{CO}_{2 \mathrm{e}}$ emissions according to European Standard EN 16258: 2012 and HBEFA calculation can only be made in tank-to-wheels assessment.

There are several studies solving emissions from buses with alternative fuels. Study [38] analyses and estimates the emission levels of LNG buses in real operation conditions in China. The research is carried out using visualization and statistical methods, which evaluate the differences in emission distribution characteristics between LNG buses and other types of buses. Subsequently, using the Gradient Boosted Regression Trees (GBRT) approach, the emission rates of some emissions are estimated for the LNG bus. A similar study [40], aimed at replacing diesel buses with alternative

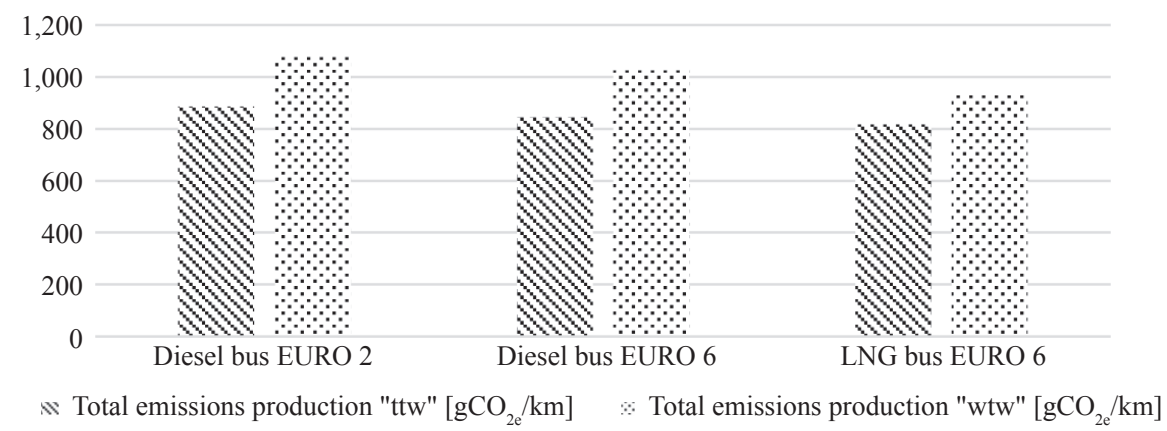

Figure 6-Overall production of GHG emissions

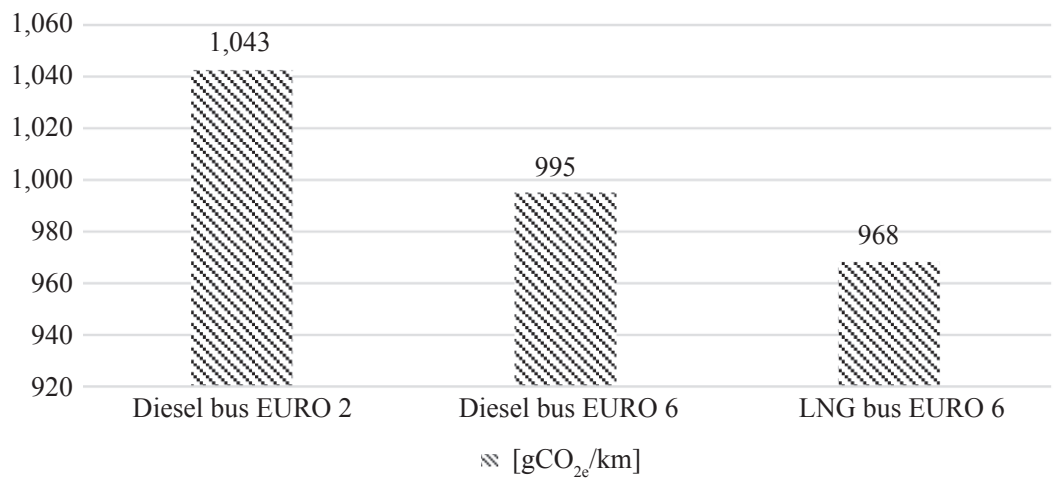

Figure 7 - Overall production of $G H G-\mathrm{CO}_{2 e}$ (HBEFA calculation) 


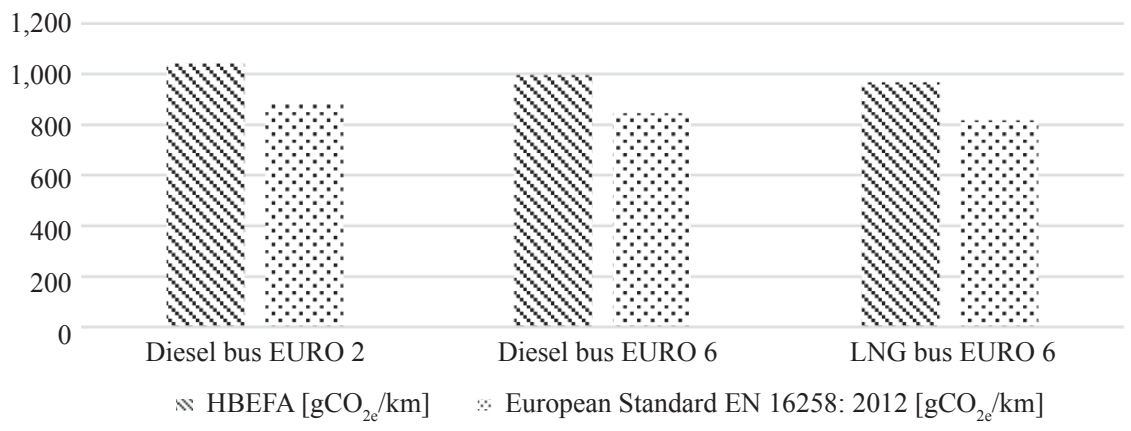

Figure 8 - Comparison of the GHG production according to European standard and HBEFA calculation

ones, was carried out in Taiwan. The measurement was performed on city buses in Tainan City according to the international standard for measuring the carbon footprint of various energy buses using the Life cycle assessment method. The results of study [41] suggest that an approximate $8.0 \%$ reduction in the life cycle of GHG emissions is estimated if diesel Heavy-Duty Vehicles (HDVs) are replaced with LNG HDVs in China. Study [42] compares changes in $\mathrm{CO}_{2}$ emissions for traditional diesel buses and compares them with new alternative buses. It uses statistical approaches that significantly affect the emission rate. The study proposes a GBRT model to perform estimates of bus $\mathrm{CO}_{2}$ emission rates. Our study, which presents a different approach in comparing the emissions by two different methods, combines GHG calculations through a standard and a GHG simulation, where the results were calculated from HBEFA based on partial emissions according to GWP.

The study also concludes that the implementation of LNG buses for the chosen region in Slovakia does not result in any energy consumption savings. The same conclusions can be drawn from studies carried out in other regions [43]. Therefore, appropriate measures must be adopted to improve the transport system in terms of resources consumed. One of the main problems with the deployment of alternative fuel buses in Slovakia is the lack of transport infrastructure. Within the framework of Directive 2014/94 / EU Alternative Fuel Infrastructure [44], the objectives and tasks aimed at creating our own functional infrastructure focused on the filling of alternative fuels (LNG, CNG, hydrogen and battery electric drivetrain) were clearly defined. Regarding LNG, it has been stipulated that LNG filling stations must be evenly distributed on the road, i.e. within $400 \mathrm{~km}$ of each other. As far as CNG is concerned, it was determined that the stations must be maximally $150 \mathrm{~km}$ apart. The results of the research have a direct impact on supporting the implementation of the mentioned directive in Slovakia in the form of two projects aimed at building the infrastructure of LNG and CNG filling stations on the main highway in the Slovak Republic. One of these projects also envisages the construction of an LNG production and storage terminal in Bratislava [45].

\section{CONCLUSION}

The study deals with issues of emission production in bus transport in the selected region of Slovakia. It compares the production of GHG emissions of the current diesel bus fleet of EURO 2, diesel buses EURO 6 and pilot tested LNG version meeting the same emission standard.

In terms of emission production, the LNG bus version produces lower emissions compared to diesel buses of both emission classes compared. However, the savings achieved are relatively low but are not negligible in terms of overall vehicle life. A possible replacement of the current diesel fleet (not only by LNG; other alternatives are possible) in almost every transport company in Slovakia would contribute to an overall reduction in emissions from transport.

The concluded comparison of the results from the conducted research shows that:

- according to the calculation based on the European Standard EN 16258: 2012 the GHG production is most convenient in the LNG bus version;

- according to the HBEFA calculation of GHG production, the most valuable option is also LNG bus.

The relevance of the results is confirmed by both ways of calculation of emissions production. The calculated $\mathrm{CO}_{2 \mathrm{e}}$ emissions according to the European Standard EN 16258: 2012 are the highest for EURO 2 diesel bus and the lowest for the LNG version. The order of HBEFA emissions calculation is the same. 
According to the European Standard EN 16258: 2012, the diesel version of the EURO 6 bus produces $3.17 \%$ more $\mathrm{CO}_{2 \mathrm{e}}$ than the LNG version. According to the calculation of HBEFA, the diesel version of the EURO 6 buses generates 2.7\% more emissions than the LNG version. As a result of the emission difference, the mean of two calculations is used, which implies that the EURO 6 diesel bus produces 2.9\% more $\mathrm{CO}_{2 \mathrm{e}}$ emissions than an LNG bus of the same emission class.

\section{ACKNOWLEDGEMENTS}

This work was supported by the Institutional research "Energy and emission intensity of road, rail and water transport vehicles" of the Grant system of the Faculty of Operation and Economics of Transport and Communications, University of Zilina. This work is also the result of the Project VEGA No. 1/0128/20: Research on the Economic Efficiency of Variant Transport Modes in the Car Transport in the Slovak Republic with Emphasis on Sustainability and Environmental Impact, Faculty of Operation and Economics of Transport and Communications, University of Zilina, 2020-2022.

MARTIN JURKOVIČ, Ing., $\mathrm{PhD}^{1}$

Email: martin.jurkovic@fpedas.uniza.sk

TOMÁŠ KALINA, Ing., $\mathrm{PhD}^{1}$

Email: tomas.kalina@fpedas.uniza.sk

TOMÁŠ SKRÚCANÝ, Ing., $\mathrm{PhD}^{1}$

Email: tomas.skrucany@fpedas.uniza.sk

PIOTR GORZELAŃCZYK, Mgr. Inz., $\mathrm{PhD}^{2}$

Email: pgorzelanczyk@pwsz.pila.pl

VLADIMÍR LUUPTÁK, Ing., $\mathrm{PhD}^{3}$

Email: luptak@mail.vstecb.cz

${ }^{1}$ Fakulta prevádzky a ekonomiky dopravy a spojov

Žilinská univerzita v Žiline

Univerzitná 1, 01026 Žilina, Slovakia

2 Štátna vysoká škola Stanislawa Staszica

v Pile ul. Podchorążych 10, Pila, Pol'sko

${ }^{3}$ Vysoká škola technická a ekonomická v Českých Budějoviciach

Okružní 517/10, České Budějovice, Česká republika

\section{POSÚDENIE ENVIRONMENTÁLNYCH VPLYVOV ZAVEDENIA LNG AKO ALTERNATÍVNEHO PALIVAV AUTOBUSOVEJ DOPRAVE: PRÍPADOVÁ ŠTÚDIA NA SLOVENSKU}

\section{ABSTRAKT}

Ciel'om článku je zhodnotit' možnosti zniženia vybraných environmentálnych ukazovatelov, akými sú spotreba energie, produkcia sklenikových plynov $(G H G)$ a d'alšich znečistujúcich látok vo vybranom regióne
Slovenska zavedením autobusov na skvapalnený zemný plyn (LNG). Posudzovanie sa vykonáva porovnaním spotreby a emisií súčasných autobusov (EURO 2) v reálnej prevádzke s potenciálnymi autobusmi (EURO 6) a testovanim pilotných autobusov $L N G$ na rovnakých trasách. Porovnanie sa uskutočnilo za rovnakých podmienok $v$ rovnakom období. V štúdii sú prezentované merania spotreby energie a produkcie sklenikových plynov jednotlivých autobusov. Výskum využiva a porovnáva dve metodiky výpočtu. Prvý výpočet je podl'a európskej normy EN 16258: 2012, ktorá špecifikuje všeobecnú metodiku hodnotenia a deklarovania spotreby energie a emisií sklenikových plynov. Druhý výpočet vychádza z Príruckky emisných faktorov pre cestnú dopravu (HBEFA). Analýzou výsledkov je navrhnutý najvhodnejši variant pre obnovu vozového parku v danom regióne.

\section{KLÚČOVÉ SLOVÁ}

skvapalnený zemný plyn; nafta; autobus; emisie; spotreba paliva;

\section{REFERENCES}

[1] Jia S, Yan G, Shen A. Traffic and emissions impact of the combination scenarios of air pollution charging fee and subsidy. Journal of Cleaner Production. 2018;197(1): 678-689. Available from: doi:10.1016/ j.jclepro.2018.06.117

[2] Slovak Republic. Strategic Transport Development Plan of the Slovak Republic up to 2030 - Phase II. Bratislava: Ministry of Transport and Construction of the Slovak Republic; 2016.

[3] Madudova E, Dávid, A. Identifying the derived utility function of transport services: Case study of rail and sea container transport. In: TRANSCOM 2019. International Scientific Conference on Sustainable, Modern and Safe Transport. 29-31 May 2019, Horný Smokovec, Slovakia. Amsterdam: Elsevier Science; 2019. p. 1096-1102.

[4] Barta D, Mruzek M. Factors influencing the hybrid drive of urban public transport buses. Management System in Production Engineering. 2015;20(4): 213-218. Available from: doi:10.12914/MSPE-04-04-2015

[5] Caulfield B, Ryan F. Examining the benefits of using bioCNG in urban bus operations. Transport Research Part D. 2010;15(6): 362-365

[6] Kalasova A, Culik K, Kubikova S. Smart City - Model of Sustainable Development of Cities. In: Automotive safety 2018. $11^{\text {th }}$ International Scientific and Technical Conference on Automotive Safety. New York, USA: Institute of Electrical and Electronics Engineers; 2018. p. 1-5.

[7] Skrucany T, Kendra M, Kalina T, Jurkovic M, Vojtek M, Synak F. Environmental Comparison of Different Transport Modes. Our sea: International Journal of Maritime Science \& Technology. 2018;65(4): 192-196.

[8] Bassi A. Liquefied natural gas (LNG) as fuel for road heavy duty vehicles technologies and standardization. SAE Pap. 2011. Available from: doi:10.4271/2011-240122

[9] Keeling CD, Piper SC, Bacastow RB, Wahlen M, 
Whorf TP, Heimann M, Meijer HA. Atmospheric $\mathrm{CO}_{2}$ and $13 \mathrm{CO} 2$ exchange with the terrestrial biosphere and oceans from 1978 to 2000. Observations and carbon cycle implications. In: Ehleringer JR, Cerling T, Dearing $\mathrm{MD}$ (Eds.) A history of atmospheric $\mathrm{CO}_{2}$ and its effects on plants, animals, and ecosystems. New York: Springer Verlag; 2005. p. 83-113.

[10] Bociaga B. Environmental impact of public transport in the Gornoslasko-zaglebiowska metropolis. Scientific Journal of Silesian University of Technology-Series Transport. 2019;103: 5-13. Available from: doi:10.20858/sjsutst.2019.103.1

[11] Korenova L. Transport and its impact on the environment in the Slovak Republic. Slovak Environmental Agency; 2013.

[12] FueLCNG. Project supported by the CEF program.

[13] Nadanyiova M. Implementation of the green marketing principles in the Slovak automotive industry. In: Transport Means 2016. Proceedings of the $20^{\text {th }}$ international scientific conference, 5-7 October 2016, Juodkrante, Lithuania. Kaunas University of Technology; 2016. p. 699-704.

[14] Yan F, Xu B, Zheng Z. Study on the Construction of an Urban Liquefied Natural Gas Bus and Its Cold Energy Recovery. Energy Procedia. 2016;104: 515-519. Available from: doi:10.1016/j.egypro.2016.12.087

[15] Sharafian A, Talebian H, Blomerus P, Herrera O, Merida W. A review of liquefied natural gas refueling station designs. Renewable and Sustainable Energy Reviews. 2017;69: 503-513. Available from: doi:10.1016/ j.rser.2016.11.186

[16] Wang A, Ge J, Tan J, Fu M, Shan A-N, Ding Y, Zhao H, Liang B. On-road pollutant emission and fuel consumption characteristics of buses in Beijing. J. Environ. Sci. 2011;23: 419-426. Available from: doi:10.1016/S10010742(10)60426-3

[17] Zhang S, Yu L, Song G. Emissions characteristics for heavy-duty diesel trucks under different loads based on vehicle-specific power. Transp. Res. Rec. J. Transp. Res. Board. 2017;2627: 77-85. Available from: doi:10.3141/2627-09

[18] Yu Q, Li T, Li H. Improving urban bus emission and fuel consumption modeling by incorporating passenger load factor for real world driving. Appl. Energy. 2016;161: 101-111. Available from: doi:10.1016/j.apenergy.2015.09.096

[19] McJeon H, Edmonds J, Bauer N, Clarke L, Fisher B, Flannery B-P, et al. Limited impact on decadal-scale climate change from increased use of natural gas. Nature. 2014;514: 482-485. Available from: doi:10.1038/ nature 13837

[20] International Gas Union. LNG as fuel. In: Proceedings of the $26^{\text {th }}$ World Gas Conference. 2015, Paris, France; 2015. p. 1-120.

[21] Caban J, Droździel P, Krzywonos L, Rybicka I- K, Šarkan B, Vrábel J. Statistical Analyses of Selected Maintenance Parameters of Vehicles of Road Transport Companies. Advances in Science and Technology Research Journal. 2019;13(1): 1-13. Available from: doi:10.12913/22998624/92106

[22] Bruglieri M, Mancini S, Pisacane O. The Green Vehicle
Routing Problem with Capacitated Alternative Fuel Stations. Computers \& Operations Research. 2019. Available from: doi:10.1016/j.cor.2019.07.017

[23] Song Q, Wang Z, Wu Y, Li J, Yu D. Duan H, Yuan W. Could urban electric public bus really reduce the GHG emissions: A case study in Macau? Journal of Cleaner Production. 2018;172: 2133-2142. Available from: doi:10.1016/j.jclepro.2017.11.206

[24] Zhao H, Burke A, Zhu L. Analysis of class 8 hybrid-electric truck technologies using diesel, LNG, electricity, and hydrogen, as the fuel for various applications. EVS27 International Battery, Hybrid and Fuel Cell Electric Vehicle Symposium, Barcelona, Spain; 2013. p. 1-16. Available from: doi:10.1109/EVS.2013.6914957

[25] Danielis R, Giansoldati M, Rotaris L. A probabilistic total cost of ownership model to evaluate the current and future prospects of electric cars uptake in Italy. Energy Policy. 2018;119: 268-281.

[26] Correa G, Munoz P, Falaguerra T, Rodriguez CR. Performance comparison of conventional, hybrid, hydrogen and electric urban buses using well to wheel analysis. Energy. 2017;141: 537-549.

[27] Enviroportal.sk. Emisie skleníkových plynov z dopravy. Available from: https://www.enviroportal.sk/indicator/ detail?id=1081\&print=yes. [Accessed 22 May 2020].

[28] Kalina T, Jurkovic M, Sapieta M, Binova H, Sapietova A. Strength Characteristics of LNG Tanks and their Application in Inland Navigation. AD ALTA-Journal of Interdisciplinary Research. 2017;7(2): 274-281.

[29] Pfoser S, Schauer O, Costa Y. Acceptance of LNG as an alternative fuel: Determinants and policy implications. Energy Policy. 2018;120: 259-267. Available from: doi:10.1016/j.enpol.2018.05.046

[30] Skrucany T, Gnap J. Energy Intensity and Greenhouse Gases Production of the Road and Rail Cargo Transport Using a Software to Simulate the Energy Consumption of a Train. In: Telematics - Support of Transport. $14^{\text {th }}$ international conference on Transport systems telematics, Katowice/Kraków/Ustroń, Poland. Selected Papers. Berlin: Springer-Verlag; 2014. p. 263-272.

[31] CEN. European standard EN 16 258:2012. Methodology for calculation and declaration of energy consumption and $G H G$ emissions of transport services (freight and passengers); 2013.

[32] HBEFA. Handbuch Emissionsfaktoren des Strassenverkehrs 3.1 - Dokumentation. BUWAL, UBA Berlin, UBA Wien; 2010. Available from: www.hbefa.net

[33] Xu J, Xuan G, Li Y, Li Z, Hu Y, Jin Y, Huang Y. Study on the squat of extra-large scale ship in the Three Gorges ship lock. Ocean Engineering. 2016;123: 65-74. Available from: doi:10.1016/j.oceaneng.2016.07.001

[34] Borge R, Miguel I, Paz D, Lumbreras J, Perez J, Rodriguez E. Comparison of road traffic emission models in Madrid (Spain). Atmospheric Environment. 2012;62: 461-471. Available from: doi:10.1016/j.atmosenv.2012.08.073

[35] Csiszar C, Sandor Z. Method for analysis and prediction of dwell times at stops in local bus transportation. Transport. 2017;32(3): 302-313. Available from: doi:10.3846/ 16484142.2016.119040

[36] U.S. Energy Information Administration. Available from: https://www.eia.gov/todayinenergy/detail.php?id=9991 
[Accessed 20 February 2020].

[37] Dizo J, Steisunas S, Blatnicky M. Vibration analysis of a coach with the wheel-flat due to suspension parameters changes. Procedia Engineering. 2017;192: 107-112. Available from: doi:10.1016/j.proeng.2017.06.019

[38] Pan Y, Chen S, Qia F, Ukkusuri S, Tang K. Estimation of real-driving emissions for buses fuelled with liquefied natural gas based on gradient boosted regression trees. Science of the Total Environment. 2019;660: 741-750. Available from: doi:10.1016/j.scitotenv.2019.01.054

[39] Pietrzak K, Pietrzak O. Environmental Effects of Electromobility in a Sustainable Urban Public Transport. Sustainability. 2020;12(1052).

[40] Chang C-C, Lia Y-T, Chang Y-W. Life cycle assessment of alternative energy types - including hydrogen - for public city buses in Taiwan. International Journal of Hydrogen Energy. 2019;44(33): 18472-18482. Available from: doi:10.1016/j.ijhydene.2019.05.073

[41] Song H, Ou X, Yuan J, Yu M, Wang C. Energy consumption and greenhouse gas emissions of diesel/LNG heavy-duty vehicle fleets in China based on a bottom-up model analysis. Energy. 2017;140(1): 966-978. Available from: doi:10.1016/j.energy.2017.09.011

[42] Pan Y, Qiao F, Tang K, Chen S, Ukkusuri SV. Understanding and estimating the carbon dioxide emissions for urban buses at different road locations: A comparison between new-energy buses and conventional diesel buses. Science of the Total Environment. 2020;703. Available from: doi:10.1016/j.scitotenv.2019.135533

[43] Song H, Ou X, Yuan J, Yu M, Wang C. Energy consumption and greenhouse gas emissions of diesel/LNG heavy-duty vehicle fleets in China based on a bottom-up model analysis. Energy. 2017;140(1): 966-978. Available from: doi:10.1016/j.energy.2017.09.011

[44] Directive 2014/94/EU of the European Parliament and of the Council of 22 October 2014 on the deployment of alternative fuels infrastructure; 2014.

[45] Galierikova A, Sosedova J. Environmental aspects of transport in the context of development of inland navigation. Ekologia Bratislava. 2016;35(3): 279-288. 